\title{
PROPAGANDA DAN TEORI KONSPIRASI: WACANA MASYARAKAT TERHADAP COVID-19 DI INDONESIA
}

\author{
Akhirul Aminulloh ${ }^{1}$ | Myrtati Dyah Artaria $^{2}$ | Latif Fianto ${ }^{3}$ | Emei Dwinanarhati Setiamandani4
}

1,2Doctoral Program of Social

Science, Airlangga University, Indonesia

${ }^{3}$ Communication Department, University of Tribhuwana

Tunggadewi, Indonesi

${ }^{4}$ Public Administration Department,

University of Tribhuwana

Tunggadewi, Indonesia

Jl. Airlangga, Airlangga, Kota

Surabaya, Jawa Timur 60286

Correspondence:

Akhirul Aminulloh

akhirul.aminulloh-2019

@fisip.unair.ac.id

\begin{abstract}
The conspiracy theory allows non-existent information to be exist. Likewise with propaganda which causes information to roll without being able to ascertain its correctness because its purpose is to manipulate public opinion. This study aims to see the complexity of the fight against the Covid-19 discourse in Indonesian society. This study used a qualitative method with a critical discourse analysis approach. Data collection was obtained from online media and social media, especially Twitter in the April 2020 period. The data were analyzed by using the Critical Discourse Analysis model of Fairclough. The result of this study indicated that it was not enough for the Covid-19 outbreak to be reported as a natural virus, but to be explored into a controversial discourse in the form of a conspiracy theory. The propaganda of the Covid-19 conspiracy theory was carried out through social media. Belief in conspiracy theory was caused by three things, they were people needed definite and reasonable answer to the phenomenon of the Covid-19 pandemic, they wanted to have control over their lives, and the impact of Post Truth era.
\end{abstract}

Keywords: Propaganda, Conspiracy Theory, Discourse, Covid-19

\begin{abstract}
Abstrak: Teori konspirasi memungkinkan adanya informasi yang tidak ada menjadi ada. Begitu pula dengan propaganda yang menyebabkan informasi bergulir tanpa dapat dipastikan kebenarannya karena tujuannya untuk memanipulasi opini publik. Penelitian ini bertujuan untuk melihat kompleksitas pertarungan wacana Covid-19 di tengah masyarakat Indonesia. Penelitian ini menggunakan metode kualitatif dengan pendekatan analisis wacana kritis. Pengumpulan data diperoleh dari media online dan media sosial, khususnya Twitter periode April 2020. Data dianalisis menggunakan model Analisis Wacana Kritis Fairclough. Hasil penelitian menunjukkan bahwa wabah Covid-19 tidak hanya dilaporkan sebagai virus alami, tetapi dieksplorasi menjadi wacana kontroversial berupa teori konspirasi. Propaganda teori konspirasi Covid-19 disebarkan melalui internet dan media sosial. Media sosial lebih dari sekadar alat untuk memantau dan membentuk pemahaman publik. Kepercayaan terhadap teori konspirasi disebabkan oleh tiga hal, yaitu masyarakat membutuhkan jawaban yang pasti dan alasan yang masuk akal atas fenomena pandemi Covid-19, ingin memiliki kendali atas hidup mereka, dan dampak dari era Post Truth.
\end{abstract}

Kata Kunci: Propaganda, Teori Konspirasi, Wacana, Covid-19 


\section{1 | PENDAHULUAN}

Virus Corona atau yang kemudian dikenal dengan Covid-19 merupakan virus yang terdapat pada manusia dan hewan serta dapat menyebabkan terjadinya infeksi pada saluran pernapasan (Ram, 2020). Penyakit ini menyebar melalui adanya interaksi hewan dan manusia (Dhama et al., 2020). Covid-19 muncul pertama kali di Hunan, sebuah pasar makanan laut di Wuhan, Cina, yang merupakan tempat penjualan kelelawar, ular, anjing rakun, dan binatang buas lain yang dijual pada Desember 2019 (Shereen et al., 2020).

Kristian Anderen, seorang pakar imunologi dan mikrobiologi pada lembaga Scripps Research mengatakan, Covid-19 merupakan virus alami yang ditularkan dari hewan seperti kelelawar. Dominic Sparkes, seorang pakar di bidang penyakit menular dari University College London menyebut bahwa virus menular Corona tidak jauh berbeda dengan SARS dan MERS, virus yang berasal dari binatang dan bukan virus yang sengaja dibuat oleh manusia atau apalagi berasal dari luar angkasa (Haryanto, 2020).

Meskipun demikian, serangan Covid-19 tetap memunculkan banyak spekulasi. Presiden Amerika Serikat Donald Trump membuat kesimpulan bahwa wabah virus Corona merupakan akibat dari kebocoran di Wuhan, Cina. Virus ini dianggap sebagai senjata biologis Cina untuk menyerang negara lain, namun kemudian mengalami kebocoran di awal tahun 2020. Negara Cina, yang tidak mau dituduh begitu saja, menyerang balik penyataan Trump dengan mengatakan bahwa virus tersebut dibawa oleh tentara Amerika Serikat yang melakukan latihan di negaranya.

Ikut mengomentari polemik tersebut, mantan Menteri Kesehatan Republik Indonesia (20042009) Siti Fadilah Supari menyinggung pernyataan Bill Gates saat mengatakan akan ada pandemi pada awal tahun dan sedang berusaha mempersiapkan vaksin. Dalam video yang diunggah di kanal Youtube Deddy Corbuzier tersebut Siti Fadilah mengatakan bahwa munculnya vaksin dalam setiap serangan pandemi bisa ditebak sebagai adanya motif terselubung (Nwy/erd, 2020). Memperjelas pernyataan tersebut, drummer grup band Superman is Dead (SID) Jerinx mengaitkan Covid-19 dengan teori konspirasi. Melalui akun instagramnya Jerinx menyatakan bahwa Covid-19 adalah skema bisnis World Health Organization (WHO) dan Bill Gates, bahkan ia bersedia menantang siapa pun untuk menyuntikkan virus corona ke tubuhnya (Tribuana, 2020). Bill Gates dianggap sebagai aktor intelektual yang menjadi dalang akan tersebarnya virus tersebut (Mahardhika, 2020).

Sebagian besar warga internet (warganet) Indonesia percaya bahwa Covid-19 adalah bencana alamiah yang tetap harus diwaspadai. Meskipun demikian, ada juga masyarakat yang percaya bahwa serangan Covid-19 adalah konspirasi kelompok elit dunia demi kepentingan ekonomi. Oleh sebab itu, informasi yang disampaikan Siti Fadilah, Jerinx atau Trump sekalipun adalah informasi yang oleh beberapa kalangan disebut sebagai teori konspirasi. Hal ini wajar, karena sejak kemunculannya serangan pandemi Covid-19 telah menjadi subjek spekulasi dan kecemasan. Masyarakat menjadi kehilangan kendali karena didera kecemasan yang mendalam sehingga lebih rentan terserang kepercayaan pada konspirasi. Daripada menganggap Covid-19 sebagai virus yang ditularkan oleh hewan atau penyakit yang terjadi secara natural, masyarakat lebih percaya bahwa wabah tersebut adalah senjata biologis Amerika Serikat dan atau Cina serta konspirasi-konspirasi lain yang sejatinya digunakan oleh mereka yang mencoba menutup perdebatan tentang masalahmasalah sensitif (Marmura, 2014). Oleh sebab itu, secara spesifik studi ini membahas tentang wacana di balik teori konspirasi Covid-19 yang dipercaya oleh sebagian kalangan masyarakat.

Teori konspirasi merujuk pada penjelasan tentang peristiwa dengan cara yang tidak beralasan, tidak masuk akal, dan mengabaikan semua bukti yang kontradiktif. Dikutip dari Karl Popper, teori ini merupakan penjelasan tentang fenomena oleh orang-orang yang tertarik dengan fenomena tersebut—kadang-kadang mengandung kepentingan tersembunyi-dan orang-orang ini telah merencanakan dan bersekongkol untuk mewujudkannya (Moore, 2016). Teori konspirasi pada dasarnya sangat berbahaya, karena dapat menjadi kendaraan bagi bangkitnya bentuk-bentuk 
pemerintahan totaliter dan menjadi ancaman keras bagi kelangsungan demokrasi liberal (Heins, 2007). Hal ini cukup rasional jika didasarkan pada konsep dasar teori konspirasi, yaitu usaha untuk menjelaskan keadaan atau peristiwa signifikan yang diakibatkan oleh tindakan jahat kelompok yang rahasia dan kuat (Douglas et al., 2019). Terlebih lagi, jika dilihat dari pandangan yang lebih psikologis, terdapat kepribadian konspirasi atau gaya berpikir paranoid, dan memandang teori konspirasi terkait erat dengan pengkambinghitaman (Stempel et al., 2007). Dalam konteks ini, teori konspirasi menjadi bentuk metode kerja propaganda dan propaganda bisa dengan mudah mengambil bentuk teori konspirasi (lžák, 2020; Marmura, 2014).

Di dalam masyarakat yang pemerintahnya cenderung menyembunyikan informasi secara sistematis dari publik, teori konspirasi kerap digunakan dan tampak rasional. Teori semacam ini dengan mudah disebarkan melalui media massa cetak maupun elektronik, namun belakangan juga mulai mudah diakses melalui media sosial. Dari fenomena covid 19 tersebut, menyebabkan sebuah kepanikan yang berupa media panic dan komodifikasi media baru (Setiyaningsih, \& Jatmikowati, 2019; Setiyaningsih, 2020). Teknologi komunikasi dan informasi memegang peranan penting dalam memainkan latar belakang diskursif yang dominan untuk menjadi dasar berkembangnya teori konspirasi. Dalam konteks ini, berbagai spekulasi dan teori konspirasi bisa ditemukan dengan mudah di berbagai platform media sosial maupun kanal-kanal semacam Youtube maupun podcast belakangan.

Lembaga media konvensional maupun media-media baru yang muncul terkemudian menyukai topik-topik yang memiliki nilai jual kepada khalayak. Media apa pun pada dasarnya sangat rentan akan kepentingan komersial (Svensson \& Edström, 2016). Apalagi jika penggunanya adalah masyarakat yang sudah berada di tengah-tengah paparan propaganda, dipenuhi kemarahan dan mudah diprovokasi. Masyarakat yang demikian sangat mudah untuk percaya pada informasi yang jauh dari benar dan objektif, sehingga hal ini menjadi celah sangat besar bagi tumbuh suburnya teori konspirasi (Klein et al., 2019).

Media sosial menjadi sarana yang mudah untuk menyebarkan dan sekaligus mengkonsumsi berbagai jenis berita saja terutama mengenai bencana yang mirip virus SARS dan MERS ini. Di tengah serangan pandemi yang melemahkan aktivitas dunia, saat di mana-mana pembatasan wilayah atau lockdown diberlakukan, platform media sosial menjadi alat aktif yang digunakan untuk komunikasi terkait bencana dan krisis kesehatan (Yu et al., 2020), maupun untuk menyebarkan berbagai bentuk propagada, teori konspirasi, dan informasi-informasi lain yang tidak dapat dipercaya (Obi-Ani et al., 2020). Dengan kemampuan penyebarannya yang cepat, luas dan serentak, media (sosial) berperan sebagai hegemon informasi dalam konteks menentukan informasi apa yang tersedia untuk khalayak dan bagaimana wacana mereka terhadap suatu masalah yang ada di dalamnya (Savrum \& Miller, 2015).

Belakangan, informasi yang disajikan oleh media sosial adalah perang opini teori konspirasi pandemi Covid-19. Melalui internet dan media sosial pihak-pihak tertentu yang antagonis menyebarkan asumsi dan menghasut publik dengan menampilkan potongan-potongan informasi yang seakan masuk akal bahwa wabah Covid-19 adalah peristiwa yang sengaja diciptakan oleh para elit untuk kepentingan politik dan ekonomi. Di berbagai sosial media tersebar ujaran untuk tidak percaya pada Covid-19 dan bahwa di baliknya terdapat pertarungan kepentingan yang hanya akan menguntungkan beberapa pihak. Teori ini semakin menyebar luas di tengah masyarakat berkat paparan propaganda. Dapat dikatakan, teori konspirasi adalah propaganda agitasi yang berhasil, yang dilakukan demi menggalang dukungan publik untuk perang, intervensi kemanusiaan, atau berharap dapat memprovokasi permusuhan publik terhadap musuh internal atau eksternal.

Itulah yang dilakukan Amerika kepada Cina dan sebaliknya, yang memang dirancang untuk menanamkan ketakutan atau kemarahan moral terhadap musuh. Dikutip dari Oxford English Dictionary, propaganda berisi informasi yang bias dan menyesatkan, digunakan untuk mempublikasikan tujuan atau sudut pandang politik (Brennan, 2017). Dalam terma lain 
sebagaimana yang dijelaskan Randal Marlin, informasi-informasi itu dikomunikasikan secara terorganisir untuk mempengaruhi keyakinan, tindakan, dan menanamkan sikap kepada banyak orang dengan cara mengelak dari penilaian individu yang terinformasi dan rasional (Brown, 2018).

\section{2 | METODE PENELITIAN}

Penelitian ini menggunakan jenis penelitian kualitatif dengan pendekatan analisis wacana kritis. Penelitian kualitatif bertumpu pada bagaimana membuat sebuah interpretasi dari apa yang dilihat, didengar, dan dipahami sehingga pemahaman yang diperoleh semakin mendalam (Creswell, 2009).

Sumber data penelitian ini adalah dokumentasi yang diambil dari media sosial Twitter melalui seperangkat software yang bisa menangkap traffic percakapan para pengguna. Data tersebut kemudian dianalisa menggunakan analisis wacana kritis model Norman Fairclough. Analisis wacana kritis dari Fairclough menekankan pada integrasi secara bersama-sama antara linguistik, pemikiran sosial dan politik, yang diintegrasikan pada perubahan sosial (Eriyanto, 2009). Kerangka analisis ini meliputi tiga dimensi, yaitu teks, discourse practice, dan sociocuktural practice. Namun penelitian ini hanya menfokuskan analisis pada tingkatan kedua dan ketiga.

\section{3 | HASIL DAN PEMBAHASAN}

\section{Wacana Teori Konspirasi Covid-19}

Virus Corona atau Covid-19 telah menjadi topik perbincangan hangat di masyarakat. Berbagai spekulasi muncul, termasuk wacana di balik munculnya penyakit tersebut. Informasi mengenai Covid-19 menjadi terpotong-potong di sana-sini. Artinya teori tentang kemunculan virus ini bersifat parsial, terutama di ruang-ruang publik dunia maya, di mana informasi bersifat nyata atau benar di ruang "sini", tetapi bertolak belakang dengan informasi yang ada di ruang "sana". Per Agustus 2020 saja Kementerian Komunikasi dan Informatika telah mendeteksi 1.016 isu hoax tentang Covid-19 yang tersebar di 1.912 platform (Halim, 2020).

Selain hoax, Covid-19 juga dikaitkan dengan teori konspirasi, topik yang menjadi pokok pembahasan penelitian ini. Virus ini dikaitkan dengan teori tentang kebocoran laboratorium di Cina, pengembangan senjata biologis mematikan, atau kemunculannya yang berasal dari angkasa. Di Indonesia, Deddy Corbuzier membicarakan virus ini sebagai teori konspirasi di kanal Youtubenya. Tokoh publik lain yang mempercayai dan melakukan propaganda atas teori konspirasi tersebut adalah I Gede Ari Astina atau Jerinx, drummer grup band Superman Is Dead (SID). Musisi kelahiran Bali tersebut menyatakan akan menyuntikkan virus Corona ke tubuhnya dan menyebut Ikatan Dokter Indonesia (IDI) sebagai kacung WHO, yang kemudian membuat dirinya menjalani proses hukum.

Melalui Twitternya Jerinx mengatakan bahwa Covid-19 adalah teori konspirasi belaka. Disebutkan bahwa Bill Gates dan WHO berada di balik kemunculan virus tersebut dan konspirasi mereka mengarah pada kepentingan bisnis. Teori ini didasarkan pada prediksi Gates yang mengatakan bahwa akan muncul virus mematikan di masa depan. Teori ini semakin menguat saat Gates dengan cepat membuat vaksin yang bisa menangkal penyakit ini dan telah mengeluarkan dana sebanyak USD 250 juta (Franedya, 2020). Teori ini dianggap sebagai kebenaran oleh sebagian kalangan masyarakat. Di Amerika Serikat, dalam beberapa kalangan tersebar konspirasi bahwa wabah Covid-19 adalah krisis dibesar-besarkan untuk menyebarkan kepanikan yang akan 
memudahkan masyarakat menerima tata dunia baru yang otoriter sebagai solusi untuk krisis. Wabah tersebut dianggap sebagai krisis yang akan menyebabkan runtuhnya sistem dunia kapitalis dan akan diikuti oleh pembentukan milenium baru yang dianggap sebagai bencana nyata, yaitu munculnya komunisme dan globalisme (Sturm \& Albrecht, 2021).

Didasarkan pada pernyataan Siti Fadilah Supari tentang adanya konspirasi di balik munculnya Covid-19 oleh Bill Gates di kanal Youtube Deddy Corbuzier, sejumlah figur publik percaya bahwa penyakit ini hanya konspirasi para elit bisnis dan tokoh negara. Sebagaimana teori konspirasi pada umumnya, daripada membahas solusi bagaimana cara menangani pandemi, orangorang sibuk mengumpulkan dan mempersoalkan potongan-potongan informasi yang sebenarnya tidak perlu dipersoalkan (Eyal, 2020). Pada akhirnya, teori konspirasi Covid-19 berakhir dengan prasangka atau kecurigaan pada satu golongan berbeda, sehingga masyarakat mampu menantang hierarki dominan sebuah sistem (Maulana, 2020), yang sebenarnya juga menyimpan motif dan tujuan terselubung di baliknya.

Pada dasarnya, virus ini telah menyebabkan berbagai krisis multidimensi di berbagai sektor. Penjarakan fisik telah menghancurkan produksi manufaktur, banyak orang kehilangan pekerjaan, perusahaan-perusahaan limbung, dan pariwisata sepi pengunjung. Penerapan PSBB di berbagai kota di Indonesia menyebabkan kerugian ekonomi (Hadiwardoyo, 2020). Maluku dan Papua menjadi yang paling buruk secara ekonomi di masa-masa pandemi, yaitu sebesar $80 \%$, sementara di bawahnya ada Bali dan Nusa Tenggara sebesar 78\% (Rahadian, 2020). Penjarakan fisik dan penerapan PSBB menyebabkan tidak hanya perusahaan manufaktur, tetapi berbagai sektor lain seperti transportasi dan kesehatan juga mengalami kerugian finansial.

Di tengah kondisi ekonomi nasional yang terus mengalami degradasi, propaganda teori konspirasi Covid-19 menyebar dengan sangat cepat. Teori konspirasi melihat pandemi sebagai rekayasa besar-besaran yang dilakukan para elit ekonomi dan politik. Masyarakat percaya pada teori ini meskipun pada hakikatnya informasi yang terkandung di dalam teori tersebut bersifat semu, karena teori konspirasi dikonstruksi dengan cara mencocok-cocokkan berbagai potongan asumsi tanpa disertai data-data akurat dan bukti-bukti empiris. Propaganda tersebut menyebabkan masyarakat menganggap Covid-19 bukan sebagai virus mematikan, sehingga mereka menentang dominasi sistem dengan cara mengabaikan protokol kesehatan. Hal ini mendorong berlangsungnya kembali berbagai aktivitas di ruang publik. Masyarakat tidak mengindahkan aturan untuk tinggal di rumah selama masa pandemi dan tetap beraktivitas di pasar, pergi berlibur, dan menyuarakan aspirasi agar objek-objek wisata yang ditutup untuk sementara segera dioperasikan. Ditambah lagi dengan tempat-tempat hiburan yang masih ramai oleh pengunjung.

Narasi teori konspirasi Covid-19 tidak muncul dari ruang hampa dan tidak bebas nilai. Konteks sosial di luar diri para penganut teori ini memberikan kontribusi yang signifikan dalam membentuk varian wacana yang muncul di berbagai platform media. Narasi wacana konspirasi yang terkandung di balik serangan Covid-19 diproduksi dan direproduksi sesuai yang situasi yang berkembang. Wacana yang muncul tentu berbeda pada saat sebelum dan sesudah pandemi Covid19 menyerang. Sebagai contoh, setelah serangan Covid-19 terdapat krisis multidimensi yang terjadi di semua sektor. Ini situasi yang mempengaruhi produksi wacana di balik teori konspirasi Covid-19.

Wacana teori konspirasi Covid-19 tidak hanya wujud dari upaya menentang dominasi sistem para elit politik, tetapi juga untuk kepentingan ekonomi media. Sebagai gambaran, sejak pandemi, banyak orang tidak terkecuali artis, kehilangan pekerjaan atau pekerjaan mereka mulai berkurang. Tentu saja hal ini berpengaruh terhadap pendapatan mereka secara finansial. Para pemilik media, pekerja media, content writer maupun content creator memproduksi teks—lebih tepatnya wacanasedemikian rupa agar menarik minat orang untuk mengkonsumsinya, dan pada akhirnya untuk menarik para pengiklan. Apalagi jika yang bersangkutan adalah tokoh publik yang memiliki banyak pengikut di berbagai platform media sosial.

Dalam terma ini, wabah Covid-19 tidak cukup hanya diberitakan sebagai sesuatu yang 
alamiah, melainkan dieksplorasi agar menjadi polemik yang dapat dijual dan menarik khalayak. Covid-19 didramatisasi sebagai peristiwa yang melibatkan kepentingan-kepentingan para penguasa. Terlebih lagi, pemerintah dianggap tidak kompeten dan terbuka dalam menangani kasus virus Corona, sehingga masyarakat menjadi skeptis terhadap pemerintah dan mengalami inkonsistensi. Di tengah kondisi yang demikian para penganut teori konspirasi mulai membangun narasi, menyambung-nyabungkan berbagai kemungkinan, percaya hanya pada informasi yang diyakini, mengabaikan fakta dan data empiris, lalu menyebarkan propaganda kepada masyarakat yang sebenarnya rentan akan informasi yang tidak benar. Ini menjadi ancaman global yang sangat serius dan dapat dijadikan alat bagi kelompok-kelompok tertentu yang ingin mengganggu sistem politik nasional.

\section{Propaganda Teori Konspirasi Covid-19}

Propaganda teori konspirasi Covid-19 menyebar secara masif dan luas sebagaimana yang dilakukan oleh penyakit itu sendiri. Hal ini wajar jika mengacu pada propaganda itu sendiri, yang menurut Jacques Ellul, ada di mana-mana dan dalam segala hal, cara yang digunakan individu atau institusi untuk memanipulasi massa dan mendorong agenda politik dan sosial (Korta, 2018).

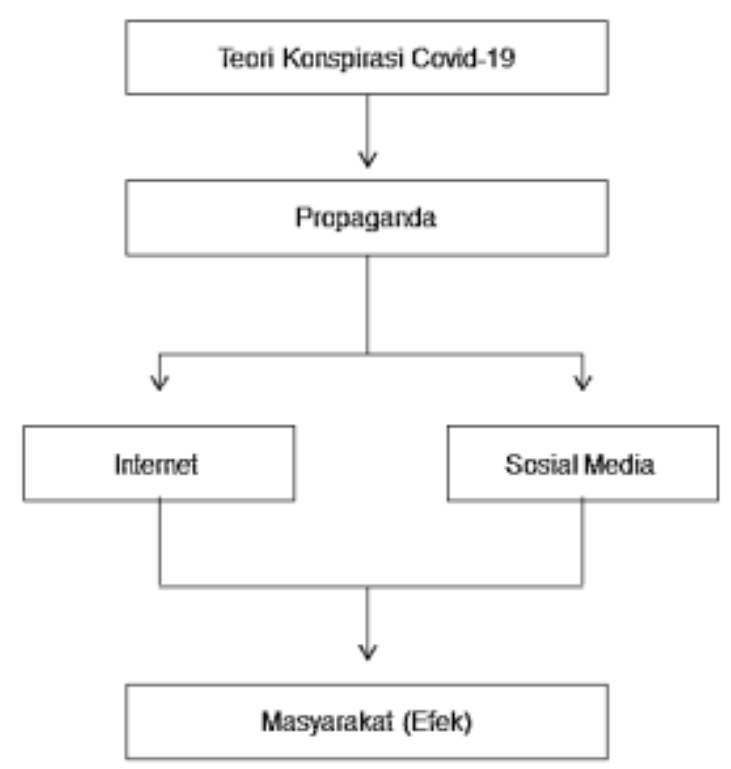

Gambar 1. Alur Propaganda Teori Konspirasi Covid-19 (Korta, 2018)

Di luar media konvensional yang perkasa, informasi di media sosial mengalir seperti air bah, tanpa adanya filterisasi mengenai informasi mana saja yang perlu dan tidak perlu untuk disebarluaskan. Di Indonesia, sepanjang April 2020, ada dua puncak topik pembicaraan di twitter, yaitu pada tanggal 22 tentang polemik atas podcast Deddy Corbuzier sebelumnya dengan Young Lex dan pada tanggal 30 tentang polemik atas tantangan Jerinx disuntik Covid karena menganggap Covid-19 hoax, dan Instagram Live dengan dokter Tirta (Fahmi, 2020).

Media sosial memegang peranan penting dalam mempropagandakan teori konspirasi Covid19. Di samping memungkinkan setiap orang dapat menjadi produsen informasi yang salah, media sosial juga lebih dari sekadar alat untuk memantau dan membentuk pemahaman publik. Media sosial menjadi sarana di garis depan dalam apa yang disebut sebagai era 'Post Truth' atau 'Berita Palsu', dengan algoritme yang digunakan untuk menyesuaikan berita dan propaganda untuk 
masyarakat (McLoughlin et al., 2020). Propaganda teori konspirasi meledak di berbagai situs berita digital dan di berbagai platform media sosial, ditambah sikap pemerintah yang sejak awal tidak terbuka mengenai data kasus Covid-19.

Polemik teori konspirasi dijadikan alat oleh pemerintah untuk mengalihkan kegagalan mereka sendiri dalam menangani kasus Covid-19 dan mencegah kritik yang datang kepada mereka. Sangat normal apabila pemerintah tidak bisa menangani berita bohong dan teori konspirasi Covid19, karena jauh sebelum Twitter atau media sosial apa pun ada, orang-orang sudah terbiasa mengguakan informasi yang tidak pasti kebenarannya sebagai mekanisme untuk bertahan hidup. Menggunakan strategi tersebut, pemerintah tergoda untuk menutupi kenyataan dengan memberikan "informasi benar" yang menjadi dasar teori konspirasi berkembang. Kini, dengan ramainya penggunaan media sosial, rumor, berita bohong dan terutama teori konspirasi menyebar dengan sangat cepat dan luas—sebuah kenyataan yang tidak bisa dianggap tidak serius.

Sebagaimana virus Covid-19 yang menyebar dari satu tubuh ke tubuh yang lain, propaganda teori konspirasi Covid-19 juga menyebar dari satu kepala ke kepala yang lain dengan sangat cepat, bahkan lebih cepat dari penyebaran virus itu sendiri. Orang-orang, apakah itu pemerintah, pekerja media, atau masyarakat sipil, menggunakan kolom di surat kabar, program siaran radio maupun televisi, atau akun Twitter dengan pengikut yang banyak, untuk menyebarkan teori konspirasi secara luas. Tidak seperti pengidap Covid-19 yang bertindak pasif, orang-orang yang terkena paparan propaganda teori konspirasi Covid-19 berusaha secara aktif untuk menyebarkannya semakin luas. Semakin banyak jumlah pengikut akun Twitter yang mereka miliki, maka semakin banyak juga masyarakat yang akan terpapar dan percaya terhadap teori tersebut.

Propaganda teori konspirasi juga tergantung pada siapa yang menyebarkan dan pihak mana yang diuntungkan. Media sosial memang menjadi sarana paling penting dalam propaganda teori konspirasi Covid-19. Tapi, pesatnya penyebaran tersebut tidak bisa dilepaskan dari dua hal. Pertama, kekuatan pihak yang menyebarkannya. Deddy Corbuzier, Young Lex, dan Jerinx adalah tokoh publik (influencer) dan memiliki banyak pengikut di Twitter. Dengan demikian, teori konspirasi menyebar dengan cepat karena didukung oleh selebritis dan influencer (Waterson \& Hern, 2020). Kedua, pihak yang diuntungkan. Di saat masyarakat berpolemik tentang teori konspirasi Covid-19, pemerintah menggunakan kesempatan ini untuk membahas persoalan lain yang dianggap signifikan. Sebagai contoh, pemerintah memaksakan diri untuk membahas rancangan undangundang seperti Omnibus Law RUU Cipta Kerja, revisi KUHP, dan RUU Pemasyarakatan di tengah berbagai krisis yang melanda masyarakat. Selain daripada itu, propaganda teori konspirasi semakin mempermudah kerja pemerintah dalam memanipulasi kegagalan mereka dalam mengantisipasi kasus Covid-19 yang semakin banyak.

\section{Faktor yang Menyebabkan Orang-Orang Percaya Teori Konspirasi Covid-19}

Propaganda teori konspirasi Covid-19 menyebabkan penanganan virus Corona terhambat, bahkan dapat menyebabkan semakin banyak masyarakat yang terinfeksi. Orang-orang yang percaya akan teori ini mengabaikan fakta bahwa virus Corona adalah penyakit menular yang mematikan. Sikap ini disebabkan oleh beberapa faktor. Pertama, orang-orang membutuhkan jawaban pasti dan masuk akal atas fenomena atau peristiwa yang kompleks. Pandemi Covid-19 yang menyebabkan kecemasan berlipat ganda dan tidak adanya kepastian mengenai obat apa yang bisa menyembuhkan dan kapan wabah ini akan berakhir, membuat sebagian orang memilih untuk percaya pada jawaban sederhana yang dapat memenuhi rasa penasaran mereka.

Teori konspirasi memberikan jawaban yang pasti bagi masyarakat yang sedang mencari jawaban atas peristiwa datangnya wabah yang kompleks. Teori ini juga memenuhi kebutuhan psikologis yang tidak terpenuhi dan memberikan keamanan pengetahuan di tengah ketidakpastian keadaan. Menurut Douglas, seorang profesor psikologi Universitas Kent, Inggris, teori konspirasi 
dapat memenuhi kebutuhan akan akurasi dan pengetahuan, juga membantu orang-orang menerima ancaman eksistensial karena informasi-informasi tersebut (teori konspirasi) dapat membantu mereka memahami ancaman situasi yang sedang mereka hadapi (Muller, 2020).

Kedua, orang-orang percaya pada teori konspirasi disebabkan oleh keinginan untuk memiliki kontrol dan kendali atas kehidupan mereka. Bagi para penganutnya, teori konspirasi cenderung memberikan rasa percaya diri dan kontrol akan gerak hidup mereka. Orang yang percaya akan teori konspirasi Covid-19 memiliki kepercayaan diri untuk tidak memenuhi protokol kesehatan dalam melakukan aktivitas di ruang publik. Mereka merasa tidak perlu mengenakan masker atau mencuci tangan, karena mereka percaya Covid-19 bukan penyakit alamiah, melainkan rekayasa para elit ekonomi dan politik belaka. Mereka menganggap ketakutan dan kecemasan yang terjadi di tengah masyarakat bukan disebabkan oleh keganasan virus, melainkan karena dramatisasi media dalam memberitakan korban virus tersebut.

Ketiga, dampak sebuah era yang disebut sebagai Post Truth. Masyarakat di era ini tidak percaya pada rasionalitas dan menjadi anti-ilmiah. Para konspirator merancang narasi palsu dengan cara menyambungkan potongan-potongan informasi yang pada dasarnya tidak memiliki hubungan signifikan dengan munculnya Covid-19. Informasi ini disebarkan dengan teknik propaganda yang meyakinkan, sehingga masyarakat yang sudah terpapar era propaganda dan apalagi berada di era Post Truth cenderung mempercayai cara berpikir mencocok-cocokkan berbagai informasi parsial yang jauh dari penting.

Pada akhirnya, para penganut teori konspirasi menganggap informasi tanpa dasar dan bukti empiris sebagai sebuah kebenaran. Hal ini terjadi karena mereka sendiri sudah anti-ilmiah dan percaya hanya pada apa yang mereka yakini, tanpa perlu melakukan pemeriksaan terhadap datadata informasi yang diterima. Teori konspirasi semakin disambut baik oleh kalangan masyarakat berpendidikan rendah yang nyaris tidak memiliki daya analisis terhadap informasi yang dikonsumsi, terutama potongan-potongan informasi yang tersebar di berbagai platform media sosial.

\section{4 | SIMPULAN DAN SARAN}

Wabah Covid-19 tidak cukup hanya diberitakan sebagai virus yang alamiah, melainkan dieksplorasi menjadi wacana kontroversial berbentuk teori konspirasi agar menjadi polemik yang bernilai jual dan menarik khalayak. Covid-19 didramatisasi sebagai peristiwa yang penuh dengan konspirasi para elit ekonomi dan politik demi kepentingan kapital. Propaganda teori konspirasi Covid-19 disebarkan melalui internet dan media sosial. Teori konspirasi meledak di berbagai situs berita digital dan di berbagai platform media sosial. Ironisnya, tidak sedikit masyarakat yang mempercayai teori konspirasi Covid-19. Hal ini disebabkan oleh beberapa faktor. Pertama, orangorang membutuhkan jawaban pasti dan masuk akal atas fenomena atau peristiwa kompleks pandemi Covid-19. Kedua, orang percaya pada teori konspirasi karena ingin memiliki kontrol dan kendali atas kehidupan mereka. Ketiga, dampak sebuah era yang disebut sebagai Post Truth. Di era ini masyarakat lebih percaya pada informasi yang mereka yakini, meskipun informasi tersebut tidak disertai data dan bukti empiris.

\section{REFERENSI}

Brennan, J. (2017). Propaganda about Propaganda. Critical Review, 29(1), 34-48. https://doi.org/10.1080/08913811.2017.1290326

Brown, É. (2018). Propaganda, Misinformation, and the Epistemic Value of Democracy. Critical Review, 30(3-4), 194-218. https://doi.org/10.1080/08913811.2018.1575007 
Creswell, W. J. (2009). Research Desain: Qualitative, Quantitative, and Mixed Methods Approaches (3rd editio). SAGE Publication.

Dhama, K., Sharun, K., Tiwari, R., Dadar, M., Malik, Y. S., Singh, K. P., \& Chaicumpa, W. (2020). COVID-19, an emerging coronavirus infection: advances and prospects in designing and developing vaccines, immunotherapeutics, and therapeutics. In Human Vaccines and Immunotherapeutics (pp. 1-13). https://doi.org/10.1080/21645515.2020.1735227

Douglas, K. M., Uscinski, J. E., Sutton, R. M., Cichocka, A., Nefes, T., Ang, C. S., \& Deravi, F. (2019). Understanding Conspiracy Theories. Political Psychology, 40(1), 1-35. https://doi.org/10.1111/pops.12568

Eriyanto. (2009). Analisis Wacana: Pengantar Analisis Teks Media. LKiS.

Eyal, J. (2020). Fatal attraction: The rise of Covid-19 conspiracy theories. Straitstimes.Com.

Fahmi, I. (2020). Teori Konspirasi dan Waras Bermedsos. Pers.Droneemprit.Id/.

Franedya, R. (2020). Covid-19 Senjata Biologis \& Teori Konspirasi Viral Lainnya. Cnbcindonesia.Com.

Hadiwardoyo, W. (2020). Kerugian Ekonomi Nasional Akibat Pandemi Covid-19. Baskara Journal of Business and Enterpreneurship, 2(2), 83-91. https://doi.org/10.24853/baskara.2.2.83-92

Halim, D. (2020). 6 Bulan Pandemi Covid-19: Hoaks dan Teori Konspirasi yang Memperparah Penanganan... Kompas.Com.

Haryanto, A. T. (2020). IImuwan Klaim Virus Corona Berasal dari Meteor Luar Angkasa. Detik.Com.

Heins, V. (2007). Critical theory and the traps of conspiracy thinking. Philosophy \& Social Criticism, 33(7), 787-801. https://doi.org/10.1177/0191453707081675

Ižák, Š. (2020). Conspiracy theory as a working method of political propaganda. Slovak Journal of Political Sciences, 20(1), 76-97. https://doi.org/10.34135/sjps.200104

Klein, C., Clutton, P., \& Dunn, A. G. (2019). Pathways to conspiracy: The social and linguistic precursors of involvement in Reddit's conspiracy theory forum. In PLoS ONE (Vol. 14, Issue 11). https://doi.org/10.1371/journal.pone.0225098

Korta, S. M. (2018). Fake News, Conspiracy Theories, And Lies: An Information Laundering Model For Homeland Security. University of Wisconsin-Madison.

Mahardhika, A. (2020). 5 Teori Konspirasi Paling Heboh Seputar Virus Corona. Detik.Com.

Marmura, S. M. E. (2014). Likely and unlikely stories: Conspiracy theories in an age of propaganda. International Journal of Communication, 8, 2377-2395.

Maulana, A. M. R. (2020). Pandemi dalam Worldviewlslam; Dari Konsepsi ke Konspirasi. Tribakti: Jurnal Pemikiran Keislaman, 31(3), 307-323. https://doi.org/10.33367/tribakti.v31i2.1232

McLoughlin, L., Ward, S., \& Lomas, D. W. B. (2020). 'Hello, world': GCHQ, Twitter and social media engagement. Intelligence and National Security, 35(2), 233-251.

https://doi.org/10.1080/02684527.2020.1713434

Moore, A. (2016). Conspiracy and Conspiracy Theories in Democratic Politics. Critical Review, 28(1), 1-23. https://doi.org/10.1080/08913811.2016.1178894

Muller, R. T. (2020). COVID-19 Brings a Pandemic of Conspiracy Theories. Psychologytoday.Com. Nwy/erd. (2020). 5 Fakta Siti Fadilah yang Blak-blakan soal Konspirasi dan Corona. Detik.Com.

Obi-Ani, N. A., Anikwenze, C., \& Isiani, M. C. (2020). Social media and the Covid-19 pandemic: Observations from Nigeria. Cogent Arts and Humanities, 7(1), 1-15. https://doi.org/10.1080/23311983.2020.1799483

Rahadian, L. (2020). Kondisi ekonomi memburuk, warga di kota paling terdampak. Lokadata.ld. Ram, S. (2020). Coronavirus Research Trends: A 50-Year Bibliometric Assessment. Science and Technology Libraries, 39(2), 210-226. https://doi.org/10.1080/0194262X.2020.1742270

Savrum, M. Y., \& Miller, L. (2015). The Role of the Media in Conflict, Peacebuilding, and International Relations. International Journal on World Peace, 2(3), 1-12. 
Setiyaningsih, L. A., \& Jatmikowati, S. H. (2019). Media Baru Dalam Komodifikasi Waktu Luang Ibu Rumah Tangga. ETTISAL: Journal of Communication, 4(1), 23-32.

Setiyaningsih, L. A. (2020). MEDIA PANICS IBU RUMAH TANGGA SETELAH MENGAKSES BERITA COVID-19 (2020). Jurnal Nomosleca, 6(2), 101-110. http://jurnal.unmer.ac.id/index.php/n/article/view/4721/2594

Shereen, M. A., Khan, S., Kazmi, A., Bashir, N., \& Siddique, R. (2020). COVID-19 infection: Origin, transmission, and characteristics of human coronaviruses. In Journal of Advanced Research (pp. 91-98). https://doi.org/10.1016/j.jare.2020.03.005

Stempel, C., Hargrove, T., \& Stempel, G. H. (2007). MEDIAU SE, SOCIAL STRUCTURE, AND BELIEF IN 9/11 CONSPIRACY THEORI. J\&MC Quarterly, 84(2), 353-372.

Sturm, T., \& Albrecht, T. (2021). 'Constituent Covid-19 apocalypses: contagious conspiracism, 5G, and viral vaccinations.' Anthropology and Medicine, 28(1), 122-139. https://doi.org/10.1080/13648470.2020.1833684

Svensson, E. M., \& Edström, M. (2016). Market-Driven challenges to freedom of expression and the interaction between the state, the market, and the media. Nordicom Review, 37(2), 1-16. https://doi.org/10.1515/nor-2016-0013

Tribuana, L. (2020). 4 Pernyataan Kontroversi Jerinx SID soal Covid-19. Okezone.Com.

Waterson, J., \& Hern, A. (2020). At least 20 UK phone masts vandalised over false $5 \mathrm{G}$ coronavirus claims. Theguardian.Com.

Yu, M., Li, Z., Yu, Z., He, J., \& Zhou, J. (2020). Communication related health crisis on social media: a case of COVID-19 outbreak. In Current Issues in Tourism (p. 1-7).

https://doi.org/10.1080/13683500.2020.1752632 